\title{
PENGARUH MODEL PEMBELAJARAN DAN MOTIVASI BELAJAR TERHADAP HASIL BELAJAR KOGNITIF PESERTA DIDIK KELAS XI IPA MADRASAH ALIYAH SYEKH YUSUF SUNGGUMINASA (STUDI PADA MATERI LARUTAN ASAM DAN BASA)
}

\author{
Felly Falentina Adam, Tabrani Gani ${ }^{1}$, Hasri $^{2}$ \\ ${ }^{1,2}$ Dosen Program Pascasarjana Universitas Negeri Makassar \\ Email:felly_falentina@yahoo.com
}

\begin{abstract}
ABSTRAK
Selama ini model pembelajaran yang sering digunakan para guru adalah model pembelajaran langsung, yang bersifat teacher centered atau pembelajaran berpusat pada guru, padahal saat ini model pembelajaran yang lebih disarankan penggunaannya adalah model pembelajaran yang bersifat student centered atau pembelajaran berpusat pada peserta didik, seperti model Pembelajaran Berbasis Masalah (PBM). Pemilihan model pembelajaran yang tepat, juga sebaiknya memperhatikan kondisi psikologis peserta didik seperti motivasi belajar yang mendorong terjadinya proses belajar, sehingga hasil belajar dapat maksimal. Penelitian ini merupakan penelitian Quasy Eksperiment yang melibatkan dua kelas XI IPA yang terdiri dari 36 Peserta didik dengan desain faktorial 2 x 3. Data diperoleh melalui angket motivasi belajar dan tes hasil belajar yang kemudian dianalisis menggunakan aplikasi SPSS 21 melalui uji Two way Anova, dengan tingkat kesalahan 5\% $(\alpha=0,05)$. Hasil penelitian menunjukkan bahwa (i) Ada perbedaan hasil belajar peserta didik setelah dibelajarkan dengan model PBM dan dibelajarkan dengan model pembelajaran langsung; (ii) Tidak ada perbedaan hasil belajar peserta didik yang memiliki motivasi tinggi, sedang dan rendah; (iii) Ada perbedaan antara selisih hasil belajar peserta didik yang memiliki motivasi tinggi, sedang dan rendah setelah dibelajarkan dengan model PBM dan setelah dibelajarkan dengan model pembelajaran langsung.
\end{abstract}

Kata kunci: PBM, Pembelajaran Langsung, Motivasi Belajar, Hasil Belajar.

\begin{abstract}
The learning model which always used by the teacher was direct learning model with teacher centered characteristic, nowdays the learning model which was more suggested was student centered learning model which centered to the students such as Problem Based Learning (PBL). The choosing of the right model, should considered the students psychology condition such as learning motivation which encouraged the learning process, so the learning result could be maximal. The research was Queasy Experiment which involved two classes XI IPA which consisted of 36 students with factorial design $2 \times 3$. The data was obtained through learning motivation questionnaire and learning result test which analyzed by using SPSS 21 application through Two Way Anova test with mistake level 5\% $(\alpha=0,05)$. The result of research showed that (i) there was a difference of the students' learning result after being taught by using PBL and direct learning model; (ii) there was no difference of learning result of the students who had high, medium and low motivation; and (iii) there was a difference of learning result of the students who had high, medium and low motivation after taught by using PBL model and direct learning model.
\end{abstract}

Keywords: PBL, Direct Learning, Learning Motivation, Learning Result. 


\section{PENDAHULUAN}

Pendidikan merupakan hal penting yang harus dimiliki oleh setiap individu. Semakin baik mutu pendidikan, semakin baik kualitas sumber daya manusia suatu bangsa. Dalam dunia pendidikan kita mengenal sekolah sebagai lembaga pendidikan formil, tempat terjadinya proses belajar mengajar dengan pelaku utama adalah guru dan peserta didik. Dalam melaksanakan tugasnya, setiap guru haruslah bisa mendesain pembelajarannya dengan pola yang sesuai dengan karakteristik setiap peserta didik dan karakteristik materi pelajarannya.

Mempelajari materi larutan asam dan basa sangat bermanfaat bagi peserta didik, karena ilmu yang dipelajari dapat diterapkan dalam kehidupan peserta didik dalam kehidupan sehari-hari dan sebagai bekal hidup dimasa mendatang, karena ilmunya dapat diterapkan dalam dunia kerja. Pengajaran materi asam basa bertujuan agar peserta didik mampu mendefinisikan konsep asam basa, dan dapat menghitung derajat kekuatan asam dan basa. Pendefinisian atau pemahaman konsep diperlukan kemampuan berpikir dan ide-ide kreatif peserta didik, sehingga guru sebaiknya menggunakan model-model pembelajaran yang bersifat konstruktif yakni pembelajaran yang terpusat pada peserta didik. Sedangkan untuk menjelaskan perhitungan derajat keasaman guru dapat juga menggunakan model pembelajaran langsung, apalagi jika dasar matematis yang dimiliki peserta didik agak rendah yang menyulitkannya dalam pemecahan masalah dalam soal-soal perhitungan.

Berdasarkan hasil wawancara dengan guru kimia kelas XI IPA di MA Syekh Yusuf menunjukkan bahwa model pembelajaran yang digunakan pada umumnya merupakan model pembelajaran yang masih berpusat pada guru. Metode yang biasa digunakan adalah metode ceramah dan diskusi. Dalam proses belajar tidak ada Lembar Kerja Peserta Didik (LKPD) yang dibagikan, guru terfokus pada buku teks sebagai sumber belajar. Sebagian peserta didik masih kurang percaya diri dalam mengemukakan pendapat, kurang mampu berpikir kritis, dan masih kurang memahami konsep dalam pemecahan masalah, hal ini dapat ditunjukkan dari hasil belajar peserta didik yang rata-rata dibawah nilai KKM.

Model pembelajaran yang berpusat pada guru yang diterapkan di MA Syekh Yusuf disebut juga model pembelajaran langsung. Model pembelajaran langsung memiliki kelebihan dalam hal kontrol guru terhadap peserta didik, dan manajemen waktu yang baik terutama dalam mengajarkan materi yang cakupannya cukup luas. Joice, B. dkk (2011). Namun dengan model pembelajaran yang berpusat pada guru ini menyebabkan peserta didik terbiasa dengan menghapal konsep yang diterima dari guru, kurang dapat mengembangkan kreativitas yang ada dalam pemikirannya. Sebaiknya di zaman sekarang, guru mencari alternatif model lain yang orientasinya ke peserta didik, yang menjadikan peserta didik sebagai subjek pembelajaran dan bukan sebagai objek, dimana guru hanya sebagai fasilitator atau sebagai pembimbing. Peserta didik yang berusaha mencari sendiri solusi dari permasalahan.

Salah satu model pembelajaran yang menjadikan peserta didik sebagai subjek adalah model Pembelajaran berbasis masalah (PBM). Hasil Penelitian Tosun dan Senocak (2013) menunjukkan bahwa PBM dapat meningkatkan sikap positif peserta didik terhadap pelajaran kimia. Demikian pula hasil penelitian Tarhan \& Sesen (2013) menunjukkan bahwa PBM adalah suatu model pembelajaran aktif yang mempunyai pengaruh positif terhadap pencapaian belajar tingkat tinggi, penguasaan konsep alternatif, dan dapat mengembangkan keterampilan sosial peserta didik. Di dalam Model PBM peserta didik yang menemukan sendiri jawaban dari permasalahan, guru hanya sebagai fasilitator. Namun bukan berarti guru tidak berperan sama sekali dalam pengajaran, guru berperan dalam pembimbingan sehingga peserta didik mampu memecahkan masalah. Menurut 
Rusman (2014) model PBM membantu peserta didik untuk menunjukkan dan memperjelas cara berpikir, serta proses berpikit kognitif yang terlibat di dalamnya. Berdasarkan uraian di atas, maka tujuan dalam penelitian ini adalah untuk mengetahui: 1) Perbedaan hasil belajar peserta didik setelah dibelajarkan dengan model PBM dan dibelajarkan dengan model pembelajaran langsung; 2) Perbedaan hasil belajar peserta didik yang memiliki motivasi tinggi, sedang dan rendah; 3) Perbedaan antara selisih hasil belajar peserta didik yang memiliki motivasi tinggi, sedang dan rendah setelah dibelajarkan dengan model PBM dan selisih hasil belajar peserta didik yang memiliki motivasi tinggi, sedang dan rendah setelah dibelajarkan dengan model pembelajaran langsung. Hasil penelitian ini nantinya diharapkan dapat bermanfaat bagi para guru sebagai bahan pertimbangan pemilihan model pembelajaran yang disesuaikan dengan kondisi psikologis peserta didik, sehingga tujuan pembelajaran dapat tercapai.

Model pembelajaran adalah kerangka konseptual atau operasional, yang melukiskan prosedur yang sistematis dalam mengorganisasikan pengalaman belajar untuk mencapai tujuan belajar tertentu dan berfungsi sebagai pedoman bagi para pengajar dalam merencanakan, dan melaksanakan aktivitas pembelajaran (Hosnan. 2014). Model dan proses pembelajaran akan menjelaskan makna kegiatan-kegiatan yang dilakukan oleh pendidik selama pembelajaran berlangsung. Model pembelajaran adalah rangkaian kegiatan pembelajaran yang berisi strategi, metode, teknik, dan media pembelajaran. Setiap pengajar atau pendidik akan beralasan mengapa dilakukan kegiatan dalam pembelajaran dengan menentukan sikap tertentu.

Model pembelajaran yang disarankan penggunaannya saat ini adalah model pembelajaran yang berpusat pada peserta didik atau student centered. Salah satu model pembelajaran yang berorientasi pada peserta didik adalah model pembelajaran berbasis masalah (PBM). Model PBM adalah model pembelajaran dengan pendekatan pembelajaran peserta didik pada masalah autentik sehingga peserta didik dapat menyusun pengetahuannya sendiri, mengembangkan inquiry, dan berpikir kepada tingkat yang lebih tinggi, mengembangkan kemandirian, dan percaya diri. Arends (Trianto, 2013). Model ini bercirikan penggunaan masalah kehidupan nyata sebagai sebagai sesuatu yang harus dipelajari peserta didik untuk melatih dan meningkatkan keterampilan berpikir kritis dan pemecahan masalah serta mendapatkan pengetahuan konsep-konsep penting, dimana tugas guru memfokuskan diri untuk membantu peserta didik mencapai keterampilan mengarahkan diri. Penerapan model PBM terdiri atas lima tahap utama yang dimulai dengan guru memperkenalkan peserta didik dengan situasi masalah dan diakhiri dengan penyajian dan analisis hasil kerja peserta didik. Sintaks atau tahapantahapan PBM disajikan dalam Tabel 1.

Tabel 1. Sintaks Model Pembelajaran Berbasis Masalah (PBM)

\begin{tabular}{|c|c|}
\hline Tahap & Perilaku Guru \\
\hline $\begin{array}{l}\text { Tahap } 1 \\
\text { Orientasi peserta } \\
\text { didik pada masalah }\end{array}$ & $\begin{array}{lr}\text { Guru menjelaskan } \\
\text { tujuan pembelajaran, } \\
\text { menjelaskan logistik } \\
\text { yang dibutuhkan, } \\
\text { mengajukan fenomena } \\
\text { atau demonstrasi atau } \\
\text { cerita rantuk } \\
\text { memunculkan masalah, } \\
\text { memotivasi peserta } \\
\text { didik untuk terlibat } \\
\text { dalam pemecahan } \\
\text { masalah yang dipilih. }\end{array}$ \\
\hline $\begin{array}{l}\text { Tahap } 2 \\
\text { Mengorganisasi } \\
\text { peserta didik untuk } \\
\text { belajar }\end{array}$ & $\begin{array}{l}\text { Guru membantu peserta } \\
\text { didik untuk } \\
\text { mendefinisikan dan } \\
\text { mengorganisasikan } \\
\text { tugas belajar yang } \\
\text { berhubungan dengan } \\
\text { masalah tersebut. }\end{array}$ \\
\hline \begin{tabular}{l}
\multicolumn{1}{c}{ Tahap 3} \\
Membimbing \\
penyelidikan \\
individual atau \\
kelompok
\end{tabular} & $\begin{array}{lr}\text { Guru mendorong } \\
\text { peserta didik untuk } \\
\text { mengumpulkan } \\
\text { informasi yang } & \text { sesuai, } \\
\text { melaksanakan } & \end{array}$ \\
\hline
\end{tabular}




\begin{tabular}{|c|c|}
\hline & $\begin{array}{l}\text { eksperimen, untuk } \\
\text { mendapatkan } \\
\text { penjelasan dan } \\
\text { pemecahan masalah. }\end{array}$ \\
\hline $\begin{array}{l}\text { Tahap } 4 \\
\text { Mengembangkan dan } \\
\text { menyajikan hasil } \\
\text { karya }\end{array}$ & $\begin{array}{l}\text { Guru membantu peserta } \\
\text { didik dalam } \\
\text { merencanakan dan } \\
\text { menyiapkan karya yang } \\
\text { sesuai seperti laporan, } \\
\text { video, dan model serta } \\
\text { membantu mereka } \\
\text { untuk berbagi tugas } \\
\text { dengan temannya. }\end{array}$ \\
\hline $\begin{array}{l}\text { Tahap 5 } \\
\text { Menganalisis dan } \\
\text { mengevaluasi proses } \\
\text { pemecahan masalah }\end{array}$ & $\begin{array}{l}\text { Guru membantu peserta } \\
\text { didik untuk melakukan } \\
\text { refleksi atau evaluasi } \\
\text { terhadap penyelidikan } \\
\text { mereka dan proses- } \\
\text { proses yang mereka } \\
\text { gunakan. }\end{array}$ \\
\hline
\end{tabular}

Sumber : Ibrahim,dkk (Trianto, 2013)

Model pembelajaran lainnya yang hingga kini masih banyak digunakan oleh para guru adalah model pembelajaran langsung. Model ini berorientasi teacher centerd atau pembelajaran berpusat pada guru. Menurut Arends (Trianto, 2013) model pembelajaran langsung adalah salah suatu pendekatan mengajar yang dirancang khusus untuk menunjang proses belajar peserta didik yang berkaitan dengan pengetahuan deklaratif dan pengetahuan prosedural yang terstruktur dengan baik yang dapat dibelajarkankan dengan pola kegiatan yang bertahap, selangkah demi selangkah. Demikian pula menurut Muijs.D dan David.R (2008) Direct instruction atau pengajaran langsung merupakan suatu gaya mengajar dimana guru terlibat aktif dalam mengusung isi pelajaran dengan mengajarkannya secara langsung kepada peserta didik di kelas. Beberapa keunggulan terpenting dari pembelajaran langsung adalah adanya fokus akademik, arahan dan kontrol guru, harapan yang tinggi terhadap perkembangan peserta didik, sistem manajemen waktu, dan atmosfir akademik yang cukup netral (Joice,B. dkk, 2011). Pengajaran langsung dapat diterapkan di bidang studi apapun, cocok untuk mengajarkan komponen-komponen keterampilan dari mata pelajaran sejarah dan sains, namun model ini paling sesuai untuk mata pelajaran yang berorientasi pada penampilan atau kinerja seperti menulis, membaca, matematika, musik dan pendidikan jasmani (Trianto, 2013).

Pada model pembelajaran langsung terdapat lima fase yang sangat penting. Guru mengawali pelajaran dengan penjelasan tentang tujuan dan latar belakang pembelajaran, serta mempersiapkan peserta didik untuk menerima penjelasan guru. Pembelajaran langsung digunakan untuk menyampaikan pelajaran yang ditransformasikan langsung oleh guru kepada peserta didik. Sintaks Model pembelajaran langsung tersebut disajikan dalam lima tahap, seperti ditunjukkan pada Tabel 2.

Tabel 2. Sintaks Model Pembelajaran Langsung

\begin{tabular}{|c|c|}
\hline Fase & Perilaku Guru \\
\hline $\begin{array}{l}\text { Fase 1 } \\
\text { Menyampaikan } \\
\text { tujuan dan } \\
\text { mempersiapkan } \\
\text { peserta didik }\end{array}$ & $\begin{array}{l}\text { Guru menjelaskan TPK, } \\
\text { informasi latar belakang } \\
\text { pelajaran, pentingnya } \\
\text { pelajaran, } \\
\text { mempersiapkan peserta } \\
\text { didik untuk belajar. }\end{array}$ \\
\hline $\begin{array}{l}\text { Fase } 2 \\
\text { Mendemonstrasikan } \\
\text { pengetahuan dan } \\
\text { keterampilan }\end{array}$ & $\begin{array}{l}\text { Guru } \\
\text { mendemonstrasikan } \\
\text { keterampilan dengan } \\
\text { benar, atau menyajikan } \\
\text { informasi tahap demi } \\
\text { tahap }\end{array}$ \\
\hline $\begin{array}{l}\text { Fase } 3 \\
\text { Membimbing } \\
\text { pelatihan }\end{array}$ & $\begin{array}{l}\text { Guru merencanakan dan } \\
\text { memberi bimbingan } \\
\text { pelatihan awal }\end{array}$ \\
\hline $\begin{array}{lr}\text { Fase } 4 & \\
\text { Mengecek } & \\
\text { pemahaman } \\
\text { memberikan } \\
\text { balik }\end{array}$ & $\begin{array}{lr}\text { Mengecek } & \text { apakah } \\
\text { peserta didik telah } \\
\text { berhasil melakukan } \\
\text { tugas dengan baik, } \\
\text { memberikan umpan } \\
\text { balik }\end{array}$ \\
\hline $\begin{array}{l}\text { Fase 5 } \\
\text { Memberikan } \\
\text { kesempatan untuk } \\
\text { pelatihan lanjutan } \\
\text { dan penerapan }\end{array}$ & $\begin{array}{l}\text { Guru memberikan } \\
\text { kesempatan peserta didik } \\
\text { untuk berlatih lebih luas, } \\
\text { dengan perhatian khusus } \\
\text { pada penerapan kepada } \\
\text { situasi yang lebih } \\
\text { kompleks }\end{array}$ \\
\hline
\end{tabular}

Sumber : Kardi \& Nur ( Trianto, 2013) 
Hal lain yang penting diperhatikan dalam proses pembelajaran adalah motivasi belajar dari setiap peserta didik. Motivasi dan belajar merupakan dua hal yang saling mempengaruhi (Uno, H.B, 2015). Belajar adalah adalah perubahan tingkah laku secara relatif permanen dan secara potensial terjadi sebagai hasil dari praktik atau penguatan (reinforced practice) yang dilandasi tujuan untuk mencapai tujuan tertentu. Sedangkan motivasi berasal dari kata motif yang artinya sebagai kekuatan yang terdapat dalam diri individu, yang menyebabkan individu tersebut bertindak atau berbuat. Motivasi dapat juga dikatakan serangkaian usaha untuk menyediakan kondisi-kondisi tertentu, sehingga seseorang mau dan ingin melakukan sesuatu, dan bila ia tidak suka, maka akan berusaha untuk meniadakan atau mengelakkan perasaan tidak suka itu (Sardiman, 2012). Sedangkan menurut Azwar.S (2010), motivasi merupakan stimulasi atau rangsangan agar perilaku terjadi sesuai dengan arah yang dikehendaki. Motivasi dipengaruhi oleh faktor dari dalam (intrinsik) dan dipengaruhi oleh faktor dari luar (ekstrinsik). Menurut Sardiman (2012) motivasi instrinsik adalah motif-motif yang menjadi aktif atau berfungsinya tidak perlu dirangsang dari luar, karena dalam diri setiap individu sudah ada dorongan untuk melakukan sesuatu. Sehingga pada hakikatnya, motivasi belajar adalah dorongan internal dan eksternal pada peserta didik yang sedang belajar untuk mengadakan perubahan tingkah laku, pada umumnya dengan beberapa indikator atau unsur yang mendukung. Hal itu mempunyai peranan besar dalam keberhasilan seseorang dalam belajar. Indikator motivasi belajar yang digunakan dalam penelitian ini adalah sebagai berikut : (1) adanya keinginan dan kebutuhan dalam belajar (2) ulet dan tekun mengerjakan tugas, (3) adanya kegiatan menarik dalam belajar, (4) memiliki harapan dan cita-cita, dan (5) berusaha mempertahankan pendapat yang diyakini kebenarannya. (indikator 1,3, dan 4 di kutip dari Hamzah B Uno, 2015; \& indikator 2 dan 5 dikutip dari Sardiman, 2012).
Hasil belajar Peserta didik adalah tingkat keberhasilan peserta didik dalam ranah kognitif atau ranah pengetahuan pada materi larutan asam dan basa. Untuk mengetahui hasil belajar peserta didik dalam ranah kognitif maka digunakan suatu alat evaluasi yakni Tes Hasil belajar (THB) dalam bentuk pilihan ganda dengan mengacu pada kompetensi dasar yang ingin dicapai. THB merupakan butir tes yang digunakan untuk mengetahui hasil belajar peserta didik dalam ranah kognitif setelah mengikuti kegiatan belajar mengajar (Trianto, 2013).

Berdasarkan tujuan dalam penelitian ini, maka dirumuskan hipotesis sebagai berikut : 1) Terdapat perbedaan hasil belajar antara peserta didik yang dibelajarkan menggunakan model PBM dengan peserta didik yang dibelajarkan menggunakan model pembelajaran langsung; 2) Terdapat perbedaan hasil belajar peserta didik yang memiliki motivasi belajar tinggi, sedang dan rendah; dan 3) Terdapat perbedaan antara selisih hasil belajar peserta didik yang memiliki motivasi tinggi, sedang dan rendah setelah dibelajarkan dengan PBM dan selisih hasil belajar peserta didik yang memiliki motivasi tinggi, sedang dan rendah setelah dibelajarkan dengan model pembelajaran langsung.

\section{METODE PENELITIAN}

Penelitian ini merupakan penelitian eksperimen semu (quasy eksperiment). yang dilaksanakan pada semester genap tahun pelajaran 2015/2016, bertempat di Madrasah Aliyah Syekh Yusuf Sungguminasa Kabupaten Gowa Provinsi Sulawesi Selatan. Desain penelitian ini adalah desain faktorial yang dikategorikan sebagai desain faktorial $2 \times 3$. Populasi adalah seluruh kelas XI IPA yang terdiri dari dua kelas, dengan teknik pengambilan sampelnya menggunakan teknik sampling jenuh dimana seluruh populasi dijadikan anggota sampel yang terbagi dalam kelas XI IPA 1 yang dibelajarkan dengan model PBM dan kelas XI IPA 2 yang dibelajarkan dengan model 
pembelajaran langsung yang masing-masing berjumlah 18 orang.

Variabel dalam penelitian ini terdiri dari dua variabel bebas yaitu variabel model pembelajaran sebagai variabel bebas manipulatif dan motivasi belajar sebagai variabel bebas atributif, serta variabel terikat adalah hasil belajar kognitif peserta didik. Sedangkan Instrumen yang digunakan adalah angket motivasi belajar dan tes hasil belajar peserta didik dan lembar keterlaksanaan model pembelajaran. Pengamatan dilakukan oleh observer yakni dua orang guru selama proses pembelajaran. Adapun langkah-langkah pelaksanaan penelitian ini dimulai dari penyiapan perangkat pembelajaran RPP dan LKPD, menyebarkan angket motivasi belajar, melaksanakan proses pembelajaran, melaksanakan posttest. Mengolah data, menganalisis serta membuat simpulan.

Data penelitian yang diperoleh berupa data motivasi belajar peserta didik sebelum diberi perlakuan model, dan data hasil belajar peserta didik. Uji prasyarat yang dilakukan adalah uji normalitas dan uji homogenitas menggunakan aplikasi SPSS 21. Uji normalitas dilakukan dengan uji Kolmogorov-Smirnov dan uji homogenitas dengan uji Lavene dengan taraf signifikan > 0,05 , untuk mengetahui apakah data berdistribusi normal dan variansnya homogen. Untuk uji hipotesis yang dilakukan dengan uji Two Way Anova atau Anova dua arah menggunakan SPSS 21 dengan taraf signifikan sebesar 0,05. Jika harga signifikan $(\alpha)<0,05$ maka $\mathrm{H}_{0}$ ditolak dan $\mathrm{H}_{1}$ diterima dan sebaliknya.

\section{HASIL PENELITIAN DAN \\ PEMBAHASAN}

\section{Hasil Penelitian}

Adapun hasil yang diperoleh pada penelitian ini adalah:

1. Uji Deskriptif

a. Deskriptif motivasi belajar peserta didik di kedua kelas eksperimen
Tabel 3. Statistik Deskriptif Motivasi Belajar

$$
\begin{array}{cccccc}
\text { N } & \text { Ran } & \text { Mini } & \text { Maxi } & \text { Mea } & \text { Std. } \\
& \text { ge } & \text { mum } & \text { mum } & n & \text { Deviati }
\end{array}
$$

\begin{tabular}{lcccccc}
\hline $\begin{array}{l}\text { motivasi } \\
\text { belajar }\end{array}$ & 18 & 30 & 86 & 116 & 103.28 & 6.781 \\
$\begin{array}{l}\text { PBM } \\
\text { motivasi } \\
\text { belajar }\end{array}$ & 18 & 44 & 71 & 115 & 94.28 & 13.459 \\
\begin{tabular}{l} 
langsung \\
\hline
\end{tabular} & & & & & & \\
\hline
\end{tabular}

Tabel 4. Jumlah sebaran Motivasi Belajar pada kelas eksperimen

\begin{tabular}{cccc}
\hline Motivasi & \multicolumn{2}{c}{ Model Pembelajaran } & \\
\cline { 2 - 3 } Belajar & PBM & Langsung & Jumlah \\
Kimia & $(\mathrm{N}=$ & $(\mathrm{N}=18)$ & \\
& $18)$ & & 11 \\
\hline Tinggi & 5 & 6 & 16 \\
Sedang & 9 & 7 & 9 \\
Rendah & 4 & 5 & \\
\hline
\end{tabular}

b. Deskriptif hasil belajar peserta didik dikedua kelas eksperimen

Tabel 5. Statistik Deskriptif Hasil Belajar

\begin{tabular}{cccccc}
$\begin{array}{c}\text { N } \\
\text { ge } \\
\text { Ran }\end{array}$ & $\begin{array}{c}\text { Mini } \\
\text { mum }\end{array}$ & $\begin{array}{c}\text { Maxi } \\
\text { mum }\end{array}$ & $\begin{array}{c}\text { Mean } \\
\text { Deviat } \\
\text { ion }\end{array}$ \\
\hline
\end{tabular}

\begin{tabular}{lcccccc}
\hline $\begin{array}{l}\text { hasil } \\
\text { belajar } \\
\text { PBM }\end{array}$ & 18 & 32 & 41 & 73 & 59.72 & 9.196 \\
$\begin{array}{l}\text { hasil } \\
\text { belajar }\end{array}$ & 18 & 50 & 27 & 77 & 47.83 & 14.468 \\
langsung & & & & & & \\
\hline
\end{tabular}

Tabel 6. Rangkuman nilai rata-rata setiap

\begin{tabular}{|c|c|c|c|c|c|}
\hline \multirow{2}{*}{$\begin{array}{c}\text { Model } \\
\text { Pembelajara } \\
\mathrm{n}\end{array}$} & \multicolumn{3}{|c|}{ Motivasi Belajar } & \multirow{2}{*}{ Total } & \multirow{2}{*}{$\begin{array}{l}\text { Rer } \\
\text { ata }\end{array}$} \\
\hline & $\begin{array}{c}\text { Ting } \\
\text { gi }\end{array}$ & $\begin{array}{c}\text { Seda } \\
\text { ng }\end{array}$ & $\begin{array}{c}\text { Rend } \\
\text { ah }\end{array}$ & & \\
\hline PBM & 55,60 & 60,22 & 63,75 & 179,57 & $\begin{array}{c}59, \\
86\end{array}$ \\
\hline $\begin{array}{l}\text { Pembelajara } \\
\text { n langsung }\end{array}$ & 46,83 & 57,71 & 35,20 & 139,75 & $\begin{array}{l}46, \\
58\end{array}$ \\
\hline
\end{tabular}
kelompok sel eksperimen 


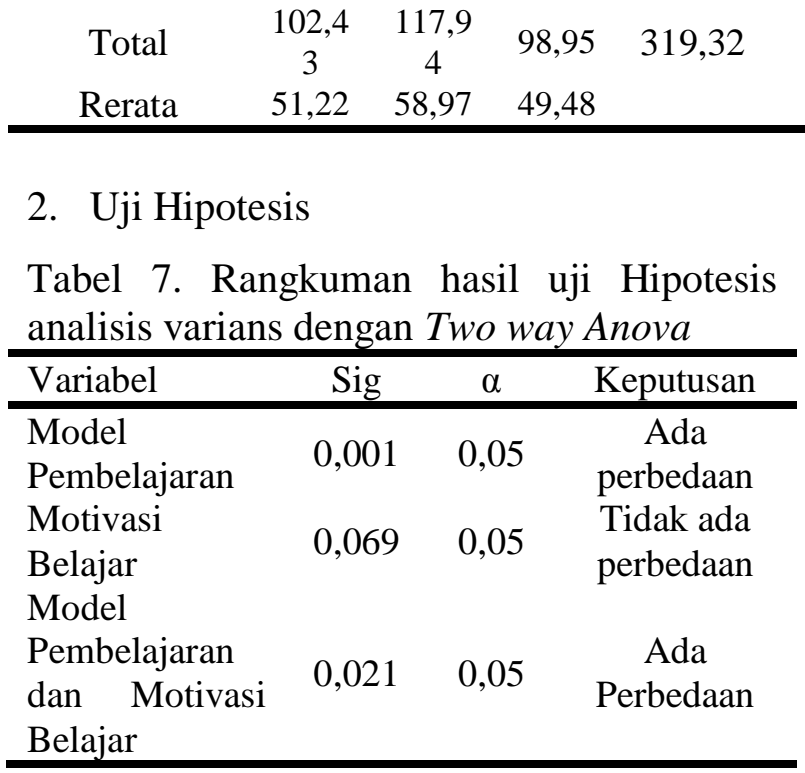

Grafik Estimated Marginal Means:

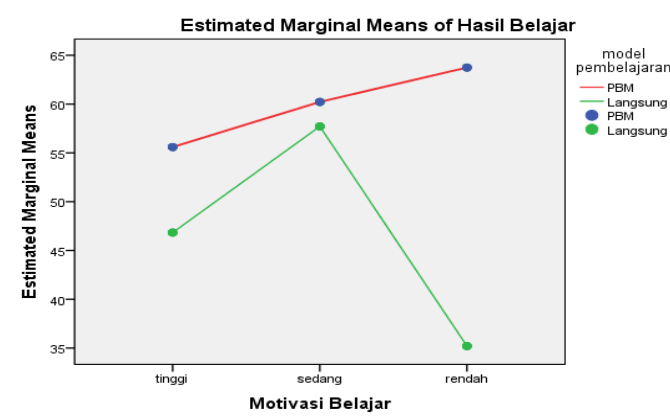

Gambar 1. Grafik interaksi antara Model Pembelajaran dan Motivasi Belajar terhadap Hasil Belajar

\section{Pembahasan Hasil Penelitian}

Adapun pembahasan dari hasil uji hipotesis pada Tabel 7, diuraikan sebagai berikut:

1. Model Pembelajaran

Hasil analisis inferensial untuk hipotesis pertama nilai signifikansinya 0,001. Nilai signifikansi model pembelajaran $0,001<\alpha$ dimana $\alpha=0,05$, yang artinya $\mathrm{H}_{0}$ ditolak dan $\mathrm{H}_{1}$ diterima. Hasil penelitian ini memperlihatkan bahwa hasil belajar kimia antar peserta didik yang dibelajarkan dengan model PBM berbeda dengan hasil belajar peserta didik yang dibelajarkan dengan model pembelajaran langsung. Perbedaan tersebut menunjukan bahwa model PBM lebih baik dari pada model pembelajaran langsung.

Model PBM dan model Pembelajaran Langsung merupakan model pembelajaran yang orientasinya berbeda satu sama lainnya. Model PBM merupakan model yang berorientasi atau berpusat pada peserta didik, sedangkan sebaliknya model pembelajaran langsung berorientasi atau berpusat pada guru. Pada model PBM ini peserta didik sendiri yang bertanggung jawab untuk membangun pengetahuan dalam pikirannya melalui kegiatan ilmiah, guru hanya sebagai fasilitator. Masalahmasalah yang diberikan selalu terkait dengan kehidupan sehari-hari peserta didik, sehingga pikiran peserta didik lebih terbuka terhadap kehidupan nyatanya yang terkait dengan materi pelajaran. Sedangkan pada kelas yang dibelajarkan dengan model pembelajaran langsung, metode yang digunakan guru adalah metode ceramah. Metode ini menyebabkan peserta didik lebih banyak menjadi pendengar dan kurang kreatif karena lebih banyak menunggu arahan atau bimbingan guru dalam belajar. Temuan ini konsisten dengan hasil penelitian Lestari (2012) menunjukkan bahwa model PBM memberikan pengaruh yang positif terhadap prestasi belajar fisika peserta didik dan Penelitian Keziah (2006) bahwa PBM dapat meningkatkan motivasi belajar peserta didik untuk belajar Biologi dibandingkan dengan pembelajaran konvensional.

2. Motivasi Belajar

Hasil penelitian menunjukkan bahwa tidak terdapat perbedaan hasil belajar kimia antara peserta didik yang memiliki motivasi belajar tinggi, sedang dan rendah pada kelas XI IPA Madrasah Aliyah Syekh Yusuf Sunggumina. Berdasarkan hasil uji dengan analisis varians two way anova, peserta didik yang memiliki motivasi tinggi, sedang, dan rendah memiliki nilai signifikansi sebesar 0,069 dimana nilai ini lebih besar dari nilai $\alpha(\alpha=0,05)$, yang artinya $\mathrm{H}_{0}$ diterima dan $\mathrm{H}_{1}$ ditolak. Tidak signifikannya nilai perbedaan hasil belajar pada kelompok motivasi disebabkan karena nilai rata-rata 
hasil belajar kognitif peserta didik yang memiliki motivasi tinggi, sedang dan rendah pada dua kelas eksperimen adalah hampir sama atau tidak jauh berbeda yaitu 51,22 untuk peserta didik yang memiliki motivasi tinggi; 58,97 untuk peserta didik yang memiliki motivasi sedang; dan 49,48 untuk peserta didik yang memiliki motivasi rendah (data pada Tabel 6).

Namun disisi lain hasil penelitian ini menunjukkan bahwa model PBM yang digunakan dapat meningkatkan hasil belajar peserta didik yang memiliki motivasi rendah, hal ini dapat disebabkan karena model PBM yang diterapkan oleh guru memberikan nuansa baru bagi peserta didik dalam belajar. Dalam model ini diperlukan kerja kelompok yang mandiri, guru hanya membantu apabila peserta didik merasa kesulitan dengan materi yang mereka bahas sendiri dengan cara memberikan umpan balik yang sifatnya memberikan saran dan perbaikan. Guru melakukan umpan balik tersebut dengan tidak membandingkan pekerjaan setiap kelompok, hal ini untuk menghilangkan perasaan minder bagi peserta didik yang berkemampuan rendah. kegiatan umpan balik yang berasal dari guru merupakan salah satu faktor yang dapat meningkatkan motivasi belajar peserta didik untuk memperbaiki dan meningkatkan kualitas pekerjaan peserta didik (Mansyur,dkk : 2015). Selain itu peserta didik yang motivasi belajarnya rendah, bila dikondisikan pada situasi belajar yang menuntut beraktivitas lebih banyak tidak hanya sebagai pendengar yang pasif maka motivasi belajarnya bisa ditingkatkan Hal ini sesuai dengan penelitian yang dilakukan oleh Sungur \& Tekkaya (2006) yang menunjukkan bahwa model PBM memberikan pengaruh yang signifikan terhadap peningkatan motivasi intrinsik peserta didik.

Demikian pula hasil penelitian ini menunjukkan bahwa model pembelajaran langsung dapat meningkatkan nilai hasil belajar peserta didik yang memiliki motivasi sedang. Hal ini dapat disebabkan karena metode yang digunakan guru adalah metode ceramah, yang lebih terfokus pada guru, sehingga peserta didik yang secara psikologis menyenangi cara mengajar gurunya, akan berusaha memperbaiki cara belajarnya. Motivasi yang berasal dari guru merupakan motivasi ekstrinsik. Motivasi ektrinsik diperlukan oleh peserta didik yang motivasi instrinsiknya kurang atau rendah. Jika guru dapat mentransfer materi pelajarannya dengan baik dan disenangi oleh peserta didik, maka hal ini dapat meningkatkan motivasi peserta didik. Penelitian ini didukung oleh penelitian Firmansyah (2010) yang menunjukkan bahwa motivasi belajar peserta didik tidak berpengaruh secara signifikan terhadap prestasi belajar Pendidikan Jasmani. Demikian pula penelitian yang dilakukan oleh Siswati, dkk (2014) yang menunjukkan bahwa tidak ada perbedaan hasil belajar antara peserta didik yang memiliki motivasi tinggi dan rendah.

3. Model pembelajaran dan Motivasi Belajar

Hasil analisis data ditunjukkan pada Grafik Estimated Marginal Means yang diperlihatkan pada Gambar 1 dan dalam Tabel 7, nampak antara model pembelajaran dan motivasi belajar terjadi interaksi karena nilai signifikansinya sebesar 0,021 lebih kecil dari alfa. Hasil penelitian ini menunjukkan kepada kita sebagai guru bahwa kondisi psikologis peserta didik seperti motivasi belajar sebaiknya ikut dipertimbangkan pada saat penyusunan perangkat skenario pembelajaran. Karena alasan keterbatasan waktu dalam proses belajar mengajar disekolah, sebagian guru membuat skenario pembelajaran dengan mengasumsikan bahwa kondisi psikologis peserta didik adalah sama. Guru saat ini lebih banyak mengacu pada pemikiran bahwa proses pembelajaran berjalan dengan baik apabila semua indikator yang telah disusun dapat dicapai. Sehingga peserta didik hanya berproses untuk belajar jika mereka berada dilingkungan sekolah dan diawasi oleh guru. Setelah peserta didik berada diluar lingkungan sekolah mereka tidak ada semangat untuk belajar, sehingga 
seharusnya guru merancang suatu skenario pembelajaran dengan mempertimbangkan motivasi belajar peserta didiknya.

Penelitian ini tidak sesuai dengan penelitian sebelumnya yang dilakukan oleh oleh Toib (2011) yang menunjukkan bahwa tidak ada interaksi yang signifikan antara model pembelajaran dan motivasi belajar terhadap hasil belajar mahasiswa. Walaupun demikian, penelitian ini juga didukung oleh penelitian yang dilakukan Lestari (2012) yang menunjukkan bahwa antara model pembelajaran dan motivasi belajar terdapat interaksi yang signifikan terhadap prestasi belajar fisika, demikian pula penelitian oleh Rusmiyanto (2012) yang menunjukkan bahwa Ada perbedaan antara model Problem Based Learning dan motivasi belajar terhadap hasil belajar bidang studi IPA/ fisika siswa kelas VIII di UPTSP SMP Negeri 1 Jetis Mojokerto.

\section{KESIMPULAN}

1. Model pembelajaran berpengaruh terhadap hasil belajar kognitif peserta didik kelas XI IPA Madrasah Aliyah Syekh Yusuf Sungguminasa.

2. Motivasi belajar tidak berpengaruh terhadap hasil belajar kognitif peserta didik kelas XI IPA Madrasah Aliyah Syekh Yusuf Sungguminasa

3. Terdapat Interaksi antara model pembelajaran dan motivasi belajar terhadap hasil belajar kognitif peserta didik kelas XI IPA Madrasah Aliyah Syekh Yusuf Sungguminasa.

\section{DAFTAR PUSTAKA}

Agung, I Gusti Ngurah. 2014. Manajemen Penyajian Analisis Data Sederhana untuk Skripsi, Tesis, dan Disertasi yang Bermutu. Depok: Rajawali Pers.

Arifin, Z. 2016. Evaluasi Pembelajaran. Prinsip Teknik, dan Prosedur. Bandung: PT Remaja Rosdakarya.

Arikunto, S. 2015. Dasar-Dasar Evaluasi Pendidikan. Jakarta: PT. Bumi Aksara
Azwar, S. 2010. Motivasi Dalam Belajar. (Online), (http : // azwar.staff. ugm. ac. id/

files/2010/05/ motivasi-dalambelajar. Pdf, diakses 20 September 2015)

Azwar. S. 2015. Penyusunan Skala Psikologi. Yogyakarta: Pustaka Pelajar

Bungel, M.F. 2014. Penerapan Model Pembelajaran Problem Based Learning Untuk Meningkatkan Hasil Belajar Siswa Kelas Viii Smp Negeri 4 Palu Pada Materi Prisma. Jurnal Elektronik Pendidikan Matematika Tadulako.

(Online)

Vol.2.No.1.(http://id.portalgaruda.or $\mathrm{g} /$ ?ref=author\&mod=profile\%id=244 798, diakses 22 April 2016)

Chang, R. 2005. KIMIA DASAR. KonsepKonsep Inti. Edisi ketiga. Jilid 2. Jakarta: Erlangga

Fadliana, H. N., Redjeki,T. \& Nurhayati,N.D. 2013. Studi Komparasi penggunaan metode PBL (Problem based learning) dilengkapi dengan Macromedia Flash dan LKS (Lembar Kerja Siswa) Terhadap Prestasi belajar ditinjau dari Motivasi Belajar Siswa Materi Asam, basa dan Garam kelas VII SMP Negeri Karanganyar tahun pelajaran 2012/2013. Jurnal Pendidikan Kimia(JPK), (online), Vol. 2 No. 3. (http:// jurnal.fkip. uns.ac.id /indeksphp/ kimia/article/viewfile/2638/1868, diakses 28 Oktober 2015)

Firmansyah, E. 2010. Pengaruh Motivasi Belajar Siswa Dan Kegiatan Ekstrakurikuler Terhadap Prestasi Belajar Pendidikan Jasmani. Thesis. (Online). (http://repository.upi.edu/ 10218/, diakses 17 April 2016)

Hosnan, M. 2014. Pendekatan Saintifik Dan Kontekstual Dalam Pembelajaran Abad 21. Kunci Sukses Implementasi Kurikulum 2013. Bogor : Ghalia Indonesia 
Ibrahim, M. 2005. Seri Pembelajaran Inovatif. Asesmen Berkelanjutan. Konsep Dasar, Tahapan Pengembangan dan Contoh. Surabaya: UNESA Press.

Joice,B., Weil,M. \& Calhaun,E. 2011. Models of Teaching. Model-Model Pengajaran. Edisi kedelapan. Yogyakarta : Pustaka Pelajar

Keziah, A.A. 2010. A comparative studyof problem-based and lecture-based learning in secondary school students' motivation to learn science. International journal of science and technology education research (online). Vol. 1(6), pp 126-131 (http:// www. Acedemic journals .org/ article/ article 1379500305 keziah. pdf, di akses 7 november 2015)

Lestari, I.N.S. 2012. Pengaruh Model Pembelajaran Berbasis Masalah (Problem Based Learning) Dan Motivasi Belajar Terhadap Prestasi Belajar Fisika Bagi Siswa Kelas VII SMP. e-jurnal,(online), Vol 1 no 2. (http://pasca. undiksha.ac.id /ejournal index.php/jurnal_tp/article/view/297, di akses 16 april 2016)

Mansyur, Rasyid, H. \& Suratno. 2015. Asesmen Pembelajaran Di Sekolah. Yogyakarta: Pustaka Pelajar

Muijs,D. \& Reynolds,D. 2008. Effective Teaching, Teori dan Aplikasi. Yogyakarta : Pustaka Pelajar.

Purba,M. 2007. Kimia 2 Untuk SMA Kelas XI. KTSP Standar Isi 2006.Jakarta : Erlangga

Rafiqah,M., Yusmansyah. \& Mayasari, S. 2013. Pengaruh Motivasi Belajar Terhadap Prestasi Belajar. Jurnal Bimbingan Konseling ALIBKIN (Online) Vol 2. No. 2 (http://jurnal.fkip.unila.ac.id/ index.php/ALIB/ article/ view/1661, diakses 21 april 2016)

Rizal, S. 2014. Pengaruh Model pembelajaran dan motivasi belajar terhadap hasil belajar kimia peserta dididk pada materi pokok larutan asam basa kelas XI IPA SMA Negeri 1 Namlea. Tesis. Tidak diterbitkan. Makassar: Program Pascasarjana UNM

Rusman. 2014. Model-Model Pembelajaran. Mengembangkan Profesionalisme Guru. Edisi kedua. Jakarta : PT Raja Grafindo Persada.

Rusmiyanto. 2012. Pengaruh Penggunaan Model Problem Based Learning Dan Motivasi Belajar Terhadap Hasil Belajar Pada Siswa Kelas VIII Di SMP Negeri 1 Jetis Kabupaten Mojokerto Thesis (Online) (http: // pasca.unesa.ac.id / s2-teknologipendidikan/jurnal/t/pengaruhpenggunaan-model-problem-based learning-dan-motivasi-belajar-terhadaphasil-belajar-pada-siswa-kelas-viii-dismp-negeri-1-jetis-kabupatenmojokerto\#artikel, di akses 21 April 2016)

Sagala,S. 2008. Konsep dan Makna Pembelajaran. Untuk Membantu Memecahkan Problematika Belajar dan Mengajar. Bandung: Alfabeta.

Sardiman. 2012. Interaksi \& Motivasi Belajar Mengajar. Jakarta : PT Raja Grafindo Persada

Semara putera, I.B.N. 2012. Implementasi Problem Based Learning (Pbl) Terhadap Hasil Belajar Biologi Ditinjau Dari Intelligence Quotient (IQ). Jurnal Penelitian Pascasarjana UNDIKSHA. (Online). Vol. 2. No. 2. (http:// pasca.undiksha.ac.id/ejournal/index.php/jurnal_ipa/article/vi ew/479, diakses 22 April 2016)

Siswati., Hariadi, E., \& Sondang,M.2014. Pengaruh Model Pembelajaran Dan Motivasi Berprestasi Terhadap Hasil Belajar Siswa Pada Materi Ms Excel. Jurnal Pendidikan Vokasi: Teori dan Praktek.. (Online). Vol 2 No 1 (http://ejournal.unesa.ac.id/ jurnal/ pendidikan-vokasi-teori-dan-praktek/ abstrak / 8699, diakses 22 april 2016) 
Sugiyono. 2015. Metode Penelitian Pendidikan. Pendekatan Kuantitatif, Kualitatif, dan $R \& D$. Bandung : Alfabeta

Sungur, S. \& Tekkaya, C. 2006. Effects of Problem-Based Learning and Traditional Instruction on Self Regulated Learning. The Journal of Educational Research. (online). Vol. 99. No.

5.

(https://fortress.wa.gov/cjtc/www/im ages/docs

/classes/PBL/Articles/effects $\% 20 \mathrm{of} \%$ 20pbl\%20learning\%20and\%20traditi onal\%20learning\%20on\%20self\%20 regulated\%20learning.pdf, diakses 21 April 2016)

Suparman, A.R. 2013. Pengaruh Strategi Pembelajaran dan Gaya Kognitif terhadap Hasil Belajar Kognitif Peserta Didik Kelas XI IPA SMA Negeri 2 Sungguminasa. Thesis. Tidak Diterbitkan. Makassar: Program Pascasarjana UNM.

Suparman, M. A. 2014. Desain Instruksional Modern. Panduan Para Pengajar dan Inovator pendidikan. Edisi Keempat. Jakarta: Erlangga

Tarhan, L. \& Sesen, B.A. 2013. Problem Based Learning in Acid and Bases : Learning Achievements And Students' Beliefs. Journal of Baltic Science Education, (Online), Vol 12, No 5. (http : // www. oaji. net/ articles/ 2015/ 987- 1425810314. pdf, di akses 28 Oktober 2015).

Tawil, M. 2011. Model Pembelajaran Sains (Berbasis Portofolio Disertai dengan Asesmen). Makassar: Badan Penerbit UNM

Toib, I. 2011. Pengaruh Model Pembelajaran Problem Based Learning Dan Ekspositori Terhadap Prestasi Belajar Pendidikan Kewarganegaraan Ditinjau Dari Motivasi Mahasiswa Program Studi Pendidikan Matematika STKIP PGRI Lumajang. Jurnal Pendidikan JP3 (Online) Vol 1 No 2 (https://jurnaljp3.files. wordpress.com /2013/09/ibnutoib.pdf, diakses 21 April 2016)

Tosun, C. \& Senocak, E. 2013. The Effects of Problem-Based Learning on Metacognitive Awareness and Attitudes toward Chemistry of Prospective Teachers with Different Academic Backgrounds. Australian Journal of Teacher Education,(Online), Vol. 38 No. 3.(http: // ro. ecu. edu. au/ ajte/ vol 38/ iss $3 / 4$, diakses 29 September 2015)

Trianto. 2013. Mendesain Model Pembelajaran Inovatif - Progresif. Konsep, landasan, dan Implementasinya pada Kurikulum Tingkat Satuan Pendidikan (KTSP). Jakarta: Kencana Prenada Media group.

Uno,H.B. 2012. Orientasi Baru Dalam Psikologi Pembelajaran. Jakarta: PT Bumi Aksara

Uno, H.B. 2015. Teori Motivasi \& Pengukurannya. Analisis Di Bidang Pendidikan. Jakarta: PT Bumi Aksara

Widoyoko,S.E.P. 2015. Teknik Penyusunan Instrumen Penelitian. Yogyakarta : Pustaka Pelajar 